\title{
Developing teachers' creative writing skills to support the school literacy program
}

\author{
Daroe Iswatiningsih ${ }^{a, 1}$, Fida Pangesti ${ }^{a, 2, *}$, Sudiran ${ }^{\mathrm{b}, 3}$ \\ ${ }^{a}$ Department of Indonesian Language Education, Faculty of Teacher Training and Education, Universitas Muhammadiyah Malang, Indonesia \\ ${ }^{\mathrm{b}}$ Department of English Education, Faculty of Teacher Training and Education, Universitas Muhammadiyah Malang, Indonesia \\ ${ }^{1}$ daroe@umm.ac.id*; 2 fidapangesti@umm.ac.id; ${ }^{3}$ sudiran@gmail.com \\ * Corresponding author
}

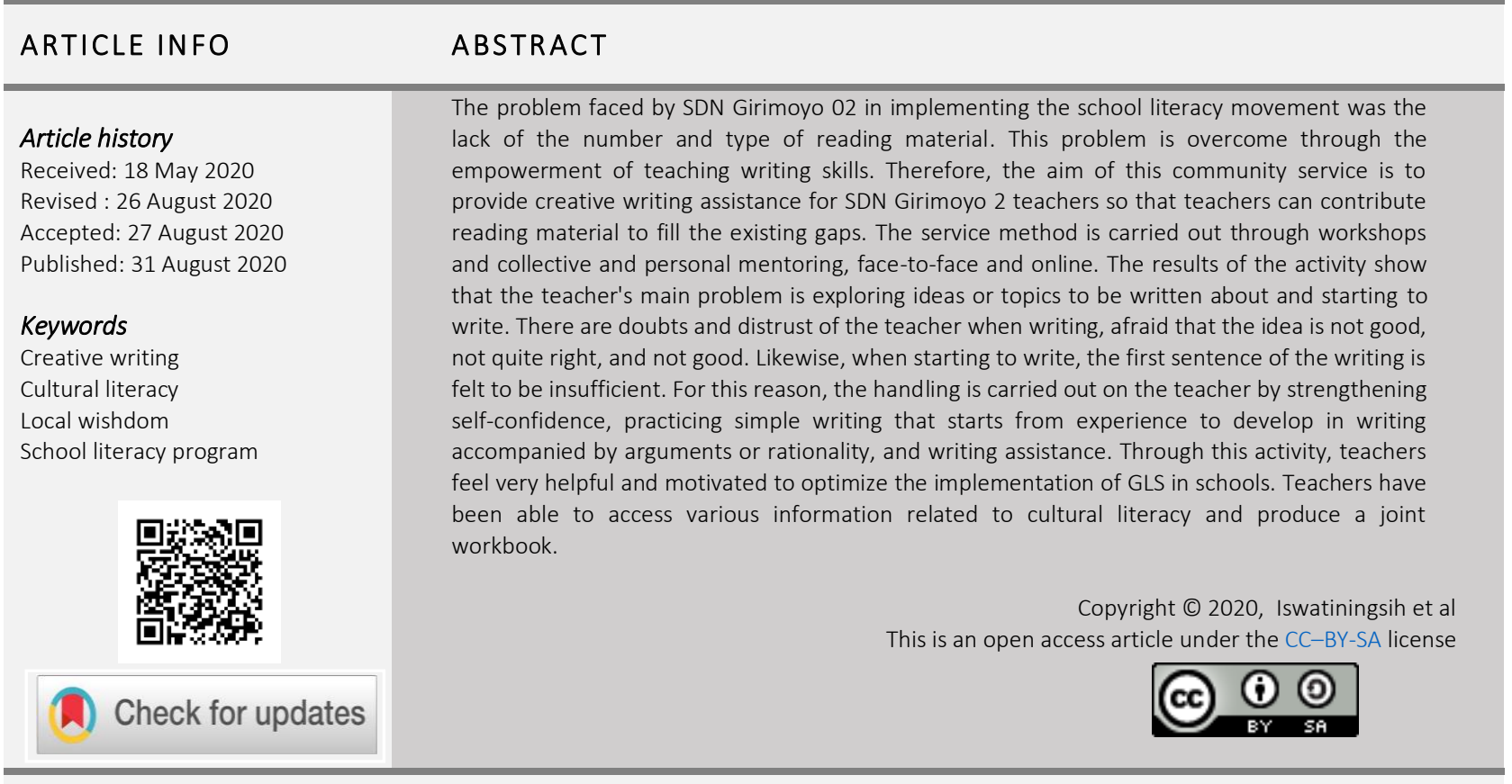

How to cite: Iswatiningsih, D., Pangesti, F., \& Sudiran, S. (2020). Developing teachers' creative writing skills to support the school literacy program. Journal of Community Service and Empowerment, 1(2), 93-101. doi: https://doi.org/10.22219/jcse.v1i2.12240

\section{PENDAHULUAN}

Pendidikan budi pekerti menjadi landasan utama mengembangkan karakter atau ranah afektif dalam pembelajaran. Fenomena degradari nilai-nilai budi pekerti atau yang sering disebut dengan degarasi moral tampak dari perilaku dan sikap remaja yang kurang mengindahkan tata aturan dan norma yang berlaku di masyarakat. Meskipun tata aturan dan norma dibuat sebagai pedoman, patokan atau ukuran untuk berperilaku atau bersikap dalam kehidupan bersama (Supriyanto, 2017). Dengan adanya aturan dan norma yang diberlakukan dan disepakati bersama, maka masyarakat menjadi disiplin. Masing-masing individu terlindungi hak-haknya dan bertanggung jawab terhadap kewajibannya. Sebaliknya, perilaku masyarakat atau remaja yang menyimpang disebabkan karena ketidakdisiplinan terhadap aturan yang berlaku, baik di dalam keluarga, masyarakat atau sekolah (Rahmawati, 2017). Penyebab ketidakdisiplinan remaja terhadap aturan yang berlaku disebabkan kurang mampu mengontrol diri serta beradaptasi dengan lingkungan. Selain bersumber dari diri sendiri, faktor lingkungan turut berperan, seperti lingkungan teman yang kurang baik serta pola asuh keluarga yang tidak mendidik membuat anak tidak disiplin dan melakukan pelanggaran. Saat ini sering diberitakan informasi tentang kasus bullying, perkelahian, pencurian, pelecehan, seks bebas, dan tindak kriminal lainnya yang dilakukan oleh anak usia sekolah. Dalam kehidupan sehari-hari tidak jarang pula dijumpai remaja dan anak-anak yang tidak menunjukkan etika dan sopan santun kepada orang yang lebih tua, bahkan melakukan tindak kekerasan dan criminal yang memprihatinkan (Detik.com, n.d.; Liputan 6 Hot, 2020; SindoNews.com, n.d.). 
Fakta di atas melatari lahirnya Permendikbud Nomor 21 Tahun 2015 tentang Penumbuhan Budi Pekerti. Pada tahap selanjutnya, Permendikbud tersebut dikembangkan menjadi sebuah program bernama Gerakan Literasi Sekolah (GLS) yang diluncurkan pada tahun 2015. Melalui Gerakan Literasi Sekolah yang berfokus pada pengembangan budaya membaca dan menulis di sekolah, diharapkan sekolah benar-benar dapat menjalankan perannya dalam menanamkan, menumbuhkan, dan mengembangkan budi pekerti.

Secara umum, gerakan literasi sekolah di sekolah dasar memiliki tiga tahapan, yaitu tahap pembiasaan, tahap pengambangan, dan tahap pembelajaran (Kemendikbud, 2016). Tahap pembiasaan berfokus pada upaya menumbuhkan minat baca anak melalui kegiatan 15 menit membaca setiap hari. Tahap pengembangan berfokus pada upaya meningkatkan kemampuan literasi melalui kegiatan menanggapi buku pengayaan. Adapun tahap pembelajaran, yakni mengimplementasikan literasi pada masing-masing mata pelajaran selama proses pembelajaran. Pada tahap ini, anggapan guru bahwa literasi hanya diterapkan pada pelajaran Bahasa Indonesia. Selain itu, implementasi literasi Tahap Pembelajaran cenderung bersifat konvensional, yakni membaca teks di buku paket atau membaca buku pengayaan di semua mata pelajaran

Bertolak dari hal di atas, maka pada dasarnya GLS selayaknya tidak hanya menerapkan literasi secara umum yang diartikan sebagai kemampuan membaca dan menulis, tetapi juga sedikit banyak memfokuskan diri pada penerapan literasi budaya. Literasi budaya merupakan kemampuan dalam memahami dan bersikap terhadap kebudayaan Indonesia sebagai identitas bangsa (Kemendikbud, 2017). Sejalan dengan pandangan tersebut, (Aprinta, 2013) menyatakan bahwa keaksaraan budaya adalah pengetahuan tentang sejarah, kontribusi dan perspektif dari kelompok budaya yang berbeda, termasuk kelompok sendiri. Literasi budaya penting dikenalkan pada generasi muda atau generasi milenial saat ini. Hal ini tidak terlepas dari peran teknologi yang memudahkan dalam menyebarkan dan memproduksi informasi budaya yang kadang mengaburkan dan membingungkan masyarakat. (Pratiwi, dkk., 2019) menyatakan bahwa implementasi literasi budaya dan kewargaan, baik pada ranah sekolah, keluarga dan masyarakat penting dilakukan sebagai solusi pengaburan informasi pada generasi milenial serta senagai upaya pelestarian kebudayaan.

Pada intinya, literasi budaya bertujuan untuk menanamkan nilai-nilai budi pekerti luhur yang memang dimiliki oleh budaya setempat. Di sisi lain, literasi budaya berfungsi sebagai filter terhadap hadirnya budaya luar atau agar tidak mengganggu enkulturasi budaya asal (Aprinta, 2013). Untuk itu, pelestarian budaya masyarakat oleh generasi muda akan tetap menjaga identitas dan keberlangsungan kehidupan masyarakatnya seperti yang dilakukan masyarakat di Desa Jurang Blimbing, Kelurahan Tembalang Kota Semarang. Meskipun perkembangan zaman bergerak cepat, namun kesenian Ketroprak, Kuda Lumping, dan Kaligrafi tetap dilestarikan agar tetap menjaga identitas bangsa (Triyono, 2019)

Hal yang terjadi di lapangan adalah bahwa ada tiga kelompok sekolah: (a) sekolah telah menerapkan GLS secara baik melalui berbagai program literasi, (b) sekolah sudah melaksanakan GLS secara terbatas, dan (c) sekolah belum melaksanakan GLS. Sekolah yang telah melaksanakan GLS dengan baik, yakni ditandai dengan diterapkannya komponen-komponen yang ditetatapkan sebagaimana dijelaskan dalam Pedoman Penilaian dan Evaluasi GLS (Kemendikbud, 2017). Selanjutnya komponen-komponen yang sudah dipetakan dalam tiap ranah GLS dikembangkan atas lima strategi penilaian setiap ranahnya, meliputi penguatan kapasitas, peningkatan jumlah dan ragam sumber belajar, perluasan akses, penguatan pelibatan public, dan penguatan tata kelola

SDN Girimoyo 02 termasuk dalam kelompok kedua. SDN Girimoyo 02 telah mengimplementasikan GLS secara terbatas atau belum optimal. Ada beberapa hal yang melatari kurang optimalnya implementasi gerakan literasi sekolah di SDN Girimoyo 02. Pertama, siswa memiliki minat baca yang relatif rendah. Kedua, tenaga pustakawan kurang sehingga proses inventarisasi buku dan pembaruan buku tidak dapat dilakukan secara teratur. Ketiga, jenis bacaan terbatas. Hal itu sejalan dengan pandangan Susilo \& Wahyuni (2017) yang menyatakan bahwa ketersediaan bahan bacaan merupakan salah satu kendala paling umum terjadi dalam pengimplementasian literasi di sekolah. Bahan bacaan yang ada di perpustakaan didominasi buku pelajaran. Buku yang nonpelajaran berupa cerita pendek, dongeng, dan puisi. Jenis buku novel, ensiklopedi, buku bergambar belum ada di perpustakaan.

Untuk mengatasi kendala-kendala yang ada, guru memiliki peran yang sentral. Peran itu berupa guru sebagai (1) motivator, (2) fasilitator, (3) teladan, (4) evaluator, dan (5) kreator bahan bacaan budaya lokal. Oleh sebab itu, program pengabdian kepada masyarakat ini bertujuan untuk membantu guru mengoptimalkan perannya dalam pelaksanaan GLS di SDN Girimoyo 02 melalui kegiatan pendampingan menulis kreatif berbasis budaya lokal.

\section{METODE}

Program pengabdian kepada masyarakat ini dilaksanakan di SDN Girimoyo 02. SDN Girimoyo 02 terletak di Jalan Diponegoro Nomor 37 Desa Girimoyo, Kecamatan Karangploso, Kabupaten Malang. Sekolah ini didirikan pada tahun 1972 dan saat ini berstatus terakreditasi B. Guru SDN Girimoyo 02 berjumlah 11 orang dan tenaga pendidik berjumlah 1 orang. Dari dua belas guru dan tenaga pendidik tersebut, hanya dua guru yang berstatus PNS. Adapun jumlah siswa yaitu 237 siswa yang terdiri dari 118 siswa laki-laki dan 119 siswa perempuan. Jumlah tersebut terbagi ke dalam 6 rombel dengan distribusi siswa yaitu 49 siswa kelas 1, 27 siswa kelas 2, 42 siswa kelas 3, 42 siswa kelas 4, 38 siswa kelas 5, dan 39 siswa kelas 6 . Pembelajaran dilaksanakan pada pagi hingga siang hari, 6 jam dalam satu hari. 


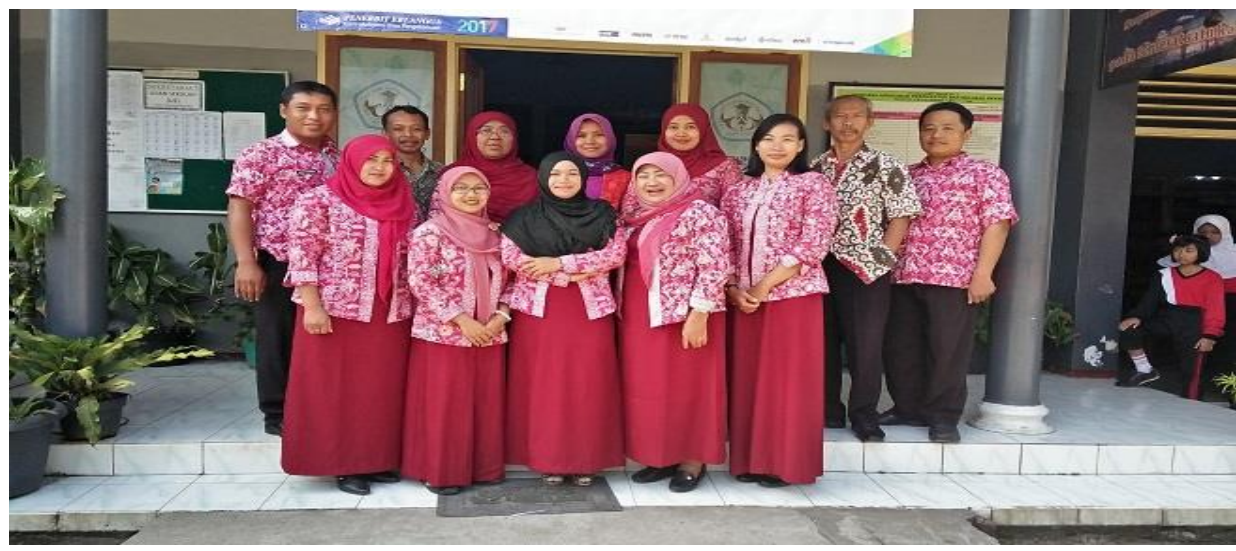

Gambar 1. Pengajar dan Tenaga Pendidik SDN Girimoyo 02

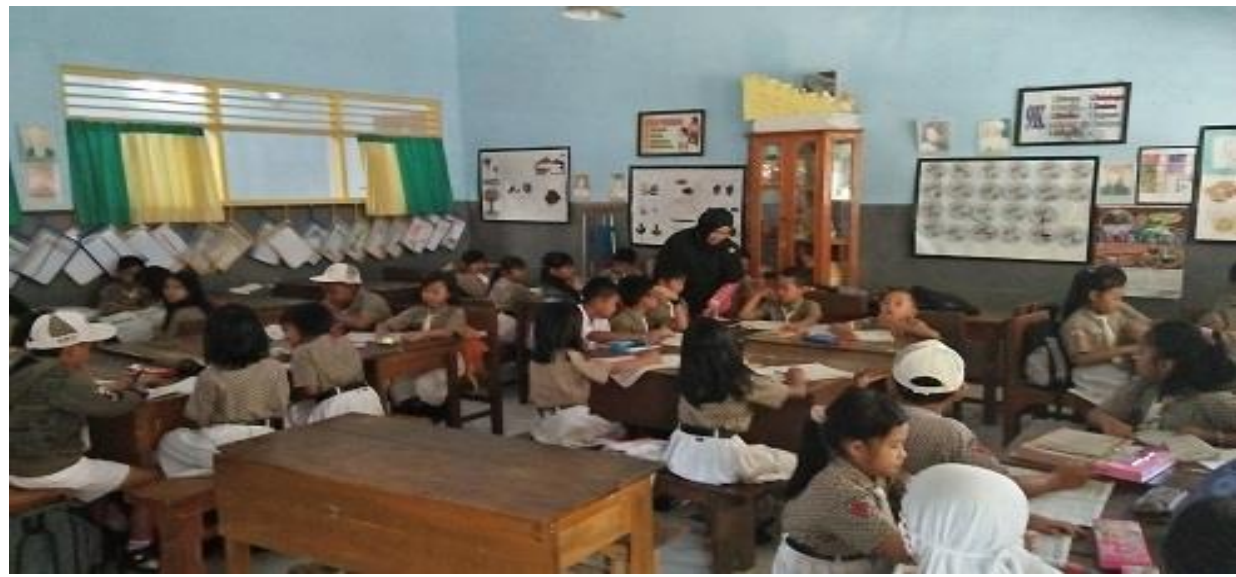

Gambar 2. KBM di SDN Girimoyo 02

Dari segi fasilitas, SD ini dapat dikategorikan baik. Sekolah ini memiliki 6 ruang kelas, ruang guru, ruang kepala sekolah, rumah dinas kepala sekolah, kantor Taman Pendidikan Al-Qur'an (TPQ), kelas ekstrakurikuler Drum band, ruang kegiatan mengaji, ruang ibadah, dan ruang perpustakaan. Ruang kelas ditata dengan baik sehingga membuat siswa nyaman dalam belajar.

Kegiatan pengabdian penulisan kreatif berbasis budaya lokal guna mendukung implementasi gerakan literasi sekolah ini diikuti oleh 14 guru SDN Girimoyo 02 dan 2 guru SDN Tegalgondo 3. Hal ini dikarenakan kedua sekolah tersebut berada di lokasi yang sama. Saat mengetahui adanya kegiatan pelatihan penulisan kreatif berbasis budaya lokal, kedua guru dari SDN Tegalgondo 3 mengajukan diri untuk mengikuti kegiatan.

Metode yang diterapkan dalam program pengabdian kepada masyarakat di SDN Girimoyo 02 ini yaitu pelatihan dan pendampingan yang terbagi dalam tiga tahap yakni (1) prakegiatan, (2) pelaksanaan kegiatan, dan (3) pasca kegiatan.

\section{Tahap prakegiatan}

Dalam tahap prakegiatan, tim pengabdi menyusun rencana awal kegiatan, merumuskan metode pelaksanaan, memetakan materi, merumuskan job description, dan menyusun jadwal kegiatan. Selanjutnya, tim pengabdi melaksanakan koordinasi dengan Kepala SDN Girimoyo 02. Koordinasi ini berfokus pada dua hal. Pertama, penggalian informasi terkait pelaksanaan GLS di SDN Girimoyo 02, ketersediaan sarana dan prasarana, serta profil guru sebagai sasaran kegiatan. Dengan adanya informasi tersebut, diharapkan tim dapat memberikan pelatihan dan pendampingan benar-benar sesuai dengan kebutuhan. Kedua, penentuan jadwal pelaksanaan kegiatan.

\section{Tahap pelaksanaan kegiatan}

Pada tahap pelaksanaan kegiatan, tim pengabdi melaksanakan kegiatan pelatihan dan pendampingan. Kegiatan pelatihan dilakukan secara tatap muka selama tiga kali pertemuan tatap muka. Adapun kegiatan pendampingan dilakukan secara nontatap muka (online) melalui email dan WhatssApp.

\section{Pelatihan menulis kreatif}

Kegiatan pelatihan dilakukan pada tahap awal setelah persiapan dan koordinasi dengan pihak mitra selesai dilakukan. Dalam kegiatan ini akan disampaikan beberapa materi kepada guru dengan target tertentu yang akan 
dicapai. Untuk mencapai target-target tersebut, diperlukan metode dan strategi yang sesuai. Metode tersebut meliputi ceramah, diskusi, dan demonstrasi yang digunakan secara bergantian sebagaimana tertera pada tabel (1) berikut ini.

Tabel 1. Kegiatan tahap pelatihan menulis kreatif

\begin{tabular}{|c|c|c|c|c|c|}
\hline \multirow{3}{*}{$\begin{array}{c}\text { No } \\
1\end{array}$} & \multirow{3}{*}{$\begin{array}{l}\text { Waktu } \\
\text { Sabtu, } 8 \text { September } \\
2018\end{array}$} & Materi & \multirow{2}{*}{$\begin{array}{l}\text { Target } \\
\text { Guru dapat lebih memahami konsep GLS dan } \\
\text { literasi budaya, memahami manfaat GLS dan } \\
\text { literasi budaya, serta memahami model-model } \\
\text { pengimplementasian GLS dan literasi budaya }\end{array}$} & \multicolumn{2}{|c|}{ Metode } \\
\hline & & $\begin{array}{l}\text { Gerakan Literasi Sekolah } \\
\text { dan Literasi Budaya }\end{array}$ & & $\begin{array}{l}\text { Ceramah } \\
\text { Diskusi }\end{array}$ & dan \\
\hline & & Genre Penulisan Kreatif & $\begin{array}{l}\text { Guru dapat memahami genre tulisan kreatif } \\
\text { berdasarkan karakteristik siswa (kelas rendah } \\
\text { dan kelas tinggi) yang dapat dihasilkan guna } \\
\text { mengoptimalkan penerapan GLS di sekolah }\end{array}$ & $\begin{array}{l}\text { Ceramah } \\
\text { Diskusi }\end{array}$ & dan \\
\hline \multirow[t]{2}{*}{2} & $\begin{array}{l}\text { Sabtu, } 15 \\
\text { September } 2018\end{array}$ & $\begin{array}{l}\text { Penggalian Ide Tulisan } \\
\text { Kreatif }\end{array}$ & $\begin{array}{l}\text { Guru dapat mendata ide tulisan kreatif dari } \\
\text { berbagai sumber yang dapat dikembangkan } \\
\text { menjadi sebuah tulisan. }\end{array}$ & $\begin{array}{l}\text { Diskusi dan } \\
\text { demonstrasi }\end{array}$ & \\
\hline & & Kerangka Tulisan Kreatif & $\begin{array}{l}\text { Guru dapat mengembangkan ide tulisan } \\
\text { kreatif dalam sebuah draft berbentuk peta } \\
\text { konsep }\end{array}$ & $\begin{array}{l}\text { Diskusi } \\
\text { demonstrasi }\end{array}$ & dan \\
\hline \multirow[t]{2}{*}{3} & $\begin{array}{l}\text { Sabtu, } 22 \\
\text { September } 2018\end{array}$ & $\begin{array}{l}\text { Aspek Kebahasaan Tulisan } \\
\text { Kreatif }\end{array}$ & $\begin{array}{l}\text { Guru dapat memahami aspek kebahasaan } \\
\text { dalam penulisan kreatif yang selaras dengan } \\
\text { sasaran tulisannya, yaitu siswa SD kelas rendah } \\
\text { dan kelas tinggi }\end{array}$ & $\begin{array}{l}\text { Ceramah } \\
\text { diskusi }\end{array}$ & dan \\
\hline & & $\begin{array}{l}\text { Manajemen Penerbitan } \\
\text { Tulisan Kreatif }\end{array}$ & $\begin{array}{l}\text { Guru dapat memahami langkah-langkah atau } \\
\text { cara menerbitkan tulisan kreatif }\end{array}$ & $\begin{array}{l}\text { Ceramah } \\
\text { diskusi }\end{array}$ & dan \\
\hline
\end{tabular}

\section{Pendampingan menulis kreatif}

Kegiatan pendampingan dilakukan saat dan setelah kegiatan pelatihan dilaksanakan. Saat kegiatan pelatihan berlangsung, pendampingan dilakukan dalam hal membantu guru menggali gagasan dan mengembangkan kerangka tulisan dalam bentuk peta konsep. Adapun pendampingan setelah pelatihan berfokus pada pendampingan penulisan kreatif dan pendampingan penerbitan karya kreatif. Dalam hal ini, karya kreatif guru diterbitkan secara mandiri dan digandakan untuk dipajang di perpusataak sekolah. Di samping itu, dilakukan pula pendampingan dalam pembuatan RTL (Rencana Tindak Lanjut). Dalam dokumen RTL, guru-guru membuat rencana kegiatan yang akan dilakukan pascaprogram pengabdian. Wujudnya dapat berupa diseminasi produk maupun workshop lanjutan dengan sekolahsekolah lain. Hal ini merupakan wujud kontribusi partisipasi mitra dan sekaligus keberlanjutan program sehingga kebermanfaatan yang diperoleh menjadi lebih besar.

Metode pendampingan yang digunakan adalah melalui tatap muka dan nontatap muka (online). Pendampingan tatap muka dilakukan dalam bentuk diskusi terkait umpan balik tulisan kreatif yang dihasilkan guru dan prosedur publikasi karya pada penerbit. Adapun pendampingan nontatap muka dilakukan secara daring melalui email dan WhatsApp. Pemilihan WhatsApp sebagai platform komunikasi dalam pendampingan nontatap muka ini bertolak dari fleksibiliitas dan kemudahan platform ini dalam mewadahi komunikasi secara real time. Dengan demikian, kegiatan pendampingan dapat dilakukan kapan saja. Pendampingan nontatap muka ini dilakukan saat guru berproses menulis kreatif. Guru dapat mengajukan pertanyaan, mengirimkan tulisan, menerima masukan, mengirimkan kembali karya kreatif yang telah direvisi, dan sebagainya sampai tulisan kreatif benar-benar selesai.

Tabel 2. Kegiatan tahap pelatihan menulis kreatif

\begin{tabular}{|c|c|c|c|}
\hline No & Pendampingan & Target & Bentuk pendampingan \\
\hline 1 & Menulis Kreatif & $\begin{array}{l}\text { Guru menghasilkan tulisan kreatif dengan berbagai genre } \\
\text { untuk mengoptimalkan Gerakan Literasi Sekolah di } \\
\text { sekolahnya }\end{array}$ & Nontatap muka (online) \\
\hline 2 & Menerbitkan Karya Kreatif & $\begin{array}{l}\text { Guru menerbitkan karya kreatif bersama dalam sebuah } \\
\text { buku yang dapat dimanfaatkan untuk mengoptimalkan } \\
\text { Gerakan Literasi Sekolah di sekolahnya }\end{array}$ & $\begin{array}{l}\text { Tatap muka dan nontatap } \\
\text { muka }\end{array}$ \\
\hline 3 & $\begin{array}{l}\text { RTL Kegiatan Menulis } \\
\text { Kreatif }\end{array}$ & $\begin{array}{l}\text { Guru menghasilkan dokumen rencana tindak lanjut } \\
\text { kegiatan menulis kreatif }\end{array}$ & $\begin{array}{l}\text { Tatap muka dan nontatap } \\
\text { muka }\end{array}$ \\
\hline
\end{tabular}

\section{Tahap pasca kegiatan}

Setelah kegiatan selesai, hal yang dilakukan tim adalah melaksanakan refleksi. Fokus utama pada kegiatan refleksi yakni menemukan kendala yang muncul selama program dan melihat sejauh mana keberhasilan serta kekurangan program. Hal ini menjadi penting demi pelaksanaan kegiatan serupa pada masa mendatang. Kegiatan refleksi ini 
dilakukan oleh tiga pihak, yaitu peserta, kepala sekolah, dan tim secara internal. Kegiatan refleksi dilaksanakan melalui metode diskusi terpumpun.

\section{HASIL DAN PEMBAHASAN}

\section{Pelatihan gerakan literasi sekolah dan literasi budaya}

Sebagaimana diuraikan sebelumnya, SDN Girimoyo 02 telah melaksanakan program gerakan literasi sekolah secara terbatas atau belum optimal. Salah satu alasannya bila dikaitkan dengan guru adalah bahwa pengetahuan guru mengenai Gerakan Literasi Sekolah dan literasi budaya masih kurang. Hal ini dapat dilihat dari sedikitnya guru yang menciptakan ruang kelas yang dapat mendukung penerapan gerakan literasi sekolah dan mengintegrasikan literasi dalam kegiatan pembelajaran. Kurangnya pemahaman guru ini disebabkan sosialisasi gerakan literasi sekolah belum terlaksana secara menyeluruh dan komprehensif dan konsep literasi budaya belum secara populer digunakan.

Berangkat dari realita di atas, materi pertama yang disampaikan adalah tentang gerakan literasi sekolah dan literasi budaya itu sendiri. Aspek khusus yang disampaikan yaitu terkait kebijakan pemerintah terkait GLS, model-model pengimplementasian GLS, dan hakikat, manfaat, dan pengimplementasian literasi budaya di sekolah. Melalui materi ini diharapkan guru memiliki wawasan yang mendalam dan memiliki gambaran pengembangan pengimplementasian GLS dan literasi budaya di SDN Girimoyo 02.

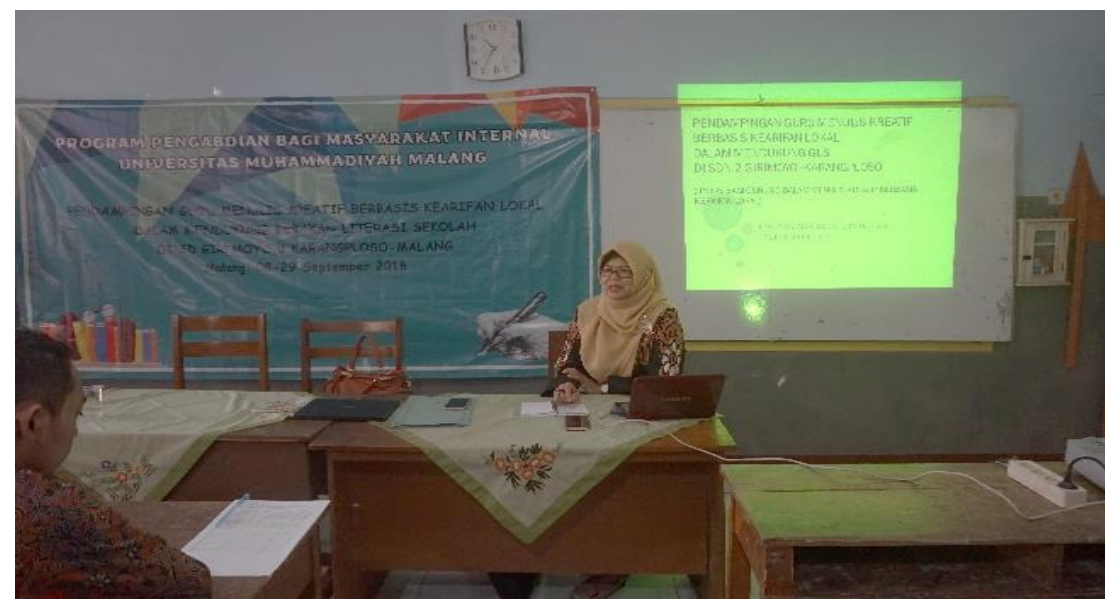

Gambar 3. Dr. Daroe Iswatiningsih Memaparkan Materi GLS dan Literasi Budaya

\section{Pelatihan dan pendampingan penulisan kreatif}

Pada tahap selanjutnya, kegiatan pengabdian difokuskan pada pelatihan dan pendampingan penulisan kreatif. Materi yang disampaikan berupa genre tulisan kreatif, aspek-aspek budaya lokal yang dapat dijadikan muatan dalam karya kreatif guru, dan aspek kebahasaan dalam penulisan kreatif.

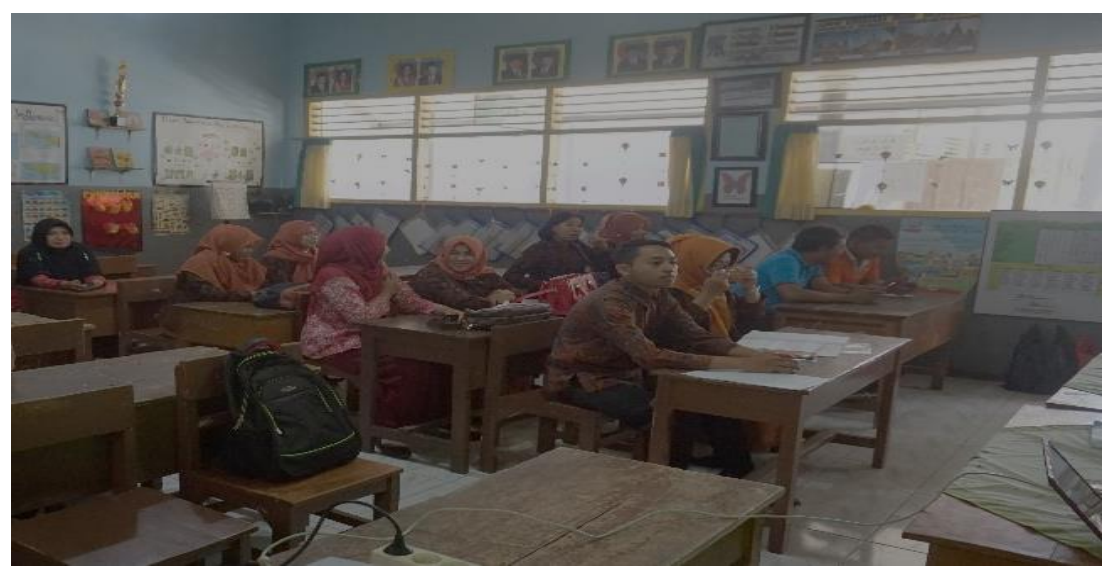

Gambar 4. Para Guru Mengikuti Pelatihan Penulisan Kreatif dengan Seksama

Kegiatan di atas dilanjutkan dengan brainstorming penggalian ide penulisan kreatif. Teknik brainstorming atau curah pendapat adalah teknik yang bertujuan untuk membantu para peserta menyalurkan sebanyak mungkin ide dan gagasan dari sajian kasus atau permasalahan yang disampaikan pemateri (Syaputra \& Mantasiah, 2017). Teknik ini efektif dalam pembelajaran menulis (Marliana et al., 2020; Syaputra \& Mantasiah, 2017) karena terbukti dapat meningkatan 
keterampilan berpikir kritis dan kreatif (Primadyaningsih et al., 2016). Teknik brainstorming ini dikombinasikan dengan teknik mind mapping atau peta konsep. Senada dengan brainstorming, peta konsep efektif dalam meningkatkan keterampilan menulis (Budiyono \& Aryanti, 2016; Musaffak \& Pangesti, 2018; Widyastuti et al., 2010). Melalui peta konsep, penulis dapat mencatat secara kreatif, efektif, dan secara harfiah akan gagasan-gagasan yang muncul (Budiyono \& Aryanti, 2016). Hal itu sejalan dengan pandangan Buzan (2013:5) yang telah menguraikan kelebihan penggunaan peta konsep, yakni (1) memberi pandangan menyeluruh pokok masalah atau area yang luas; (2) memungkinkan merencanakan rute bagi ingatan, yaitu mengingat informasi atau fakta lebih mudah dan lebih bisa diandalkan dibandingkan menggunakan teknik mencatat tradisional; (3) mengumpulkan sejumlah data dalam satu tempat; (4) mendorong pemecahan masalah dengan kreasi baru; dan (5) menyenangkan untuk dilihat, dibaca, dicerna, dan diingat.

Hasil kegiatan brainstorming yang telah dituangkan ke dalam peta konsep kemudian dituangkan dalam lembar kerja kerangka tulisan. Berbeda dengan kegiatan sebelumnya, pada kegiatan ini guru sudah secara detail menuliskan unsurunsur intrinsik dalam karya yang akan ditulis, terutama pada bagian alur cerita. Kerangka tulisan ini berfungsi sebagai pedoman bagi penulis dalam mengorganisasikan gagasan, mempercepat proses penulisan, menciptakan variasi tulisan yang diinginkan, dan mengoptimalkan kualitas bahasa pada tulisan (Budiyono, 2012). Dalam hal ini, tim pengabdi melakukan pendampingan secara intensif kepada guru-guru, baik pada proses penggalian ide maupun penuangan ide dalam kerangka karangan.

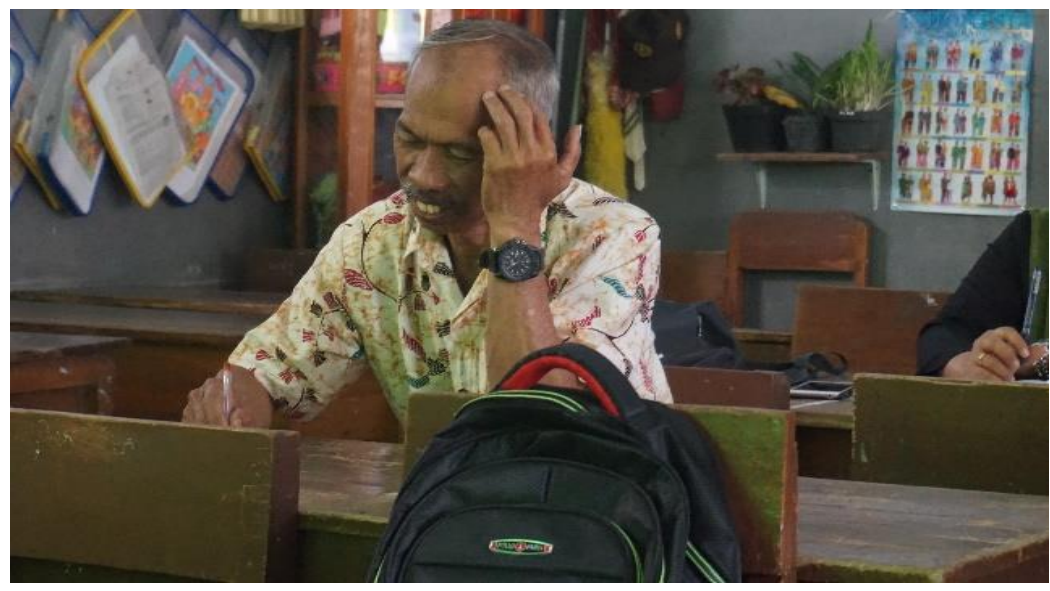

Gambar 4. Peserta Melakukan Kegiatan Brainstorming Dan Menulis Peta Konsep

Setelah kegiatan penyusunan kerangka tulisan selesai, tim melakukan proses pendampingan terhadap guru-guru SDN Girimoyo 02 untuk menuangkan kerangka tulisan ke dalam draf karya kreatif. Mengingat kegiatan ini membutuhkan konsentrasi khusus, maka kegiatan dilakukan secara nontatap muka atau online. Guru mengirimkan tulisan yang telah dibuat ke email atau WA tim untuk selanjutnya dikoreksi oleh tim dan direvisi oleh guru yang bersangkutan.

Dari proses pelatihan dan pendampingan ini, guru SDN Girimoyo 02 telah menghasilkan satu buku karya bersama. Buku tersebut berisi lima belas karya kreatif guru dengan genre yang bervariasi. Genre tersebut meliputi puisi, cerpen, teks deskripsi, dan catatan singkat. Dalam hal ini, konten yang diangkat berkaitan dengan kearifan budaya lokal. Kearifan budaya lokal yaitu konsep, ide, dan gagasan budaya lokal yang bersifat bijaksana dan dijadikan pedoman hidup masyarakat (Oktavianti. et al., 2017). Kearifan budaya lokal ini perlu dikuasai siswa karena pada akhirnya siswa akan menjadi bagian dari masyarakat dan berperan penting dalam pewarisan budaya itu sendiri. Di samping itu, tulisan dikembangkan dengan memerhatikan karakter budaya bangsa yang dikembangkan di sekolah dasar sebagaimana dinyatakan Rosala (2017), yaitu (a) mampu merasakan kasih sayang, (b) meniru sikap, nilai, dan perilaku orang lain, (c) menghargai, memberikan, dan menerima, (d) mencoba memahami orang lain di lingkungan sekitar, (e) mengenal sopan santun, (f) mengenal dan mempraktikkan aturan sekolah, (g) mengenal otoritas.

Sehubungan dengan hal tersebut, beberapa topik tulisan yang dikembangkan guru berkaitan dengan peserta didik seperti: (1) budaya sopan santun pada anak-anak pada orang yang lebih tua atau guru, (2) budaya disiplin peserta didik untuk membuang sampah bik di sekolah maupun di rumah, (3) sikap disiplin, tertib dan bertanggung jawab terhadap tugas dan pekerjaan rumah yang diberikan guru, (4) sikap dan budaya menjaga kebersihan lingkungan, baik di kelas, lingkungan sekolah dan rumah, dan sebagainya. Di samping itu, topik yang dikembangkan guru ada pula yang berkaitan dengan budaya sosial masyarakat setempat seperti: (1) kesenian Bantengan di Malang, (2) tari topeng Malangan, (3) tradisi Tedhak Siti di Jawa, dan (4) dolanan atau permainan tradisionl yang saat ini sudah banyak ditinggalkan. 
Berikut merupakan salah satu karya kreatif guru SDN Girimoyo 02.

\section{SEBELUM KAU PERGI, TEMAN}

Dear temanku,

Boleh aku bicara tentang perpisahan kita nanti? Engkau tentu sudah tahu: di mana ada pertemuan pasti akan ada perpisahan; kalau ada awal, pasti ada akhir. Itulah hidup.

Tapi, aku tidak menyesali pertemuan ataupun perpisahan kita. Di dalam hidupku, banyak orang yang datang dan pergi.

Ada yang singkat, tapi membekas di hati.

Ada yang lama, tetapi tak ada cerita istimewa.

Ada pula yang begitu jauh di mata, tetapi dekat di hati.

Semua orang yang pernah singgah dalam hidupku telah melengkapi dan membentuk aku.

Pertemuan kita memang akan menjadi kenangan. Tapi itu juga bukti kalau kita pernah belajar bersama. Belajar banyak hal, termasuk belajar tentang maaf. Aku ingat, dulu kita pernah bertengkar. Aku yang salah, tapi kamu yang minta maaf. Itu membuatku malu. Dari sana, aku berjanji pada diri sendiri untuk tidak egois dan tidak marah-marah lagi. Kamu selalu tersenyum. Senyum tulus yang menjadi energi hari-hariku.

Teman, perpisahan mengajarkanku untuk semakin mencintai karena Allah SWT. Aku jadi ingat sabda Nabi SAW yang menerangkan tentang tujuh golongan yang akan mendapatkan naungan Allah pada hari yang tiada naungan selain dari-Nya. Di antara golongan tersebut adalah:

عَلَيْهِه وَتَفَرَقَّا عَلَيْهِ اجْتَمَعَا اللَّهِ فِفَ تَحَابَّا وَرَجُلاَنِ

"Dua orang yang saling mencintai karena Allah. Mereka berkumpul dan berpisah dengan sebab cinta karena Allah." (HR. Bukhari no. 660 dan Muslim no. 1031).

Orang yang mencinta karena Allah akan dikumpulkan bersama orang yang dicinta di akhirat kelak, insha Allah.

Ya, memang manusia diciptakan tidak ada yang sempurna. Masing-masing mempunyai kelebihan dan kelemahan. Maka dari itu, manusia disebut makhluk sosial kan? Akhirnya kita bisa saling melengkapi. Kelemahanku adalah kelebihanmu; kelemahanmu adalah kelebihanku. Kita hidup saling melengkapi dan saling mengisi seperti sepasang sepatu yang tidak pernah saling cemburu.

Teman, bertemu denganmu adalah sebuah takdir, berteman denganmu adalah sebuah pilihan, bersahabat denganmu adalah sebuah kesempatan, dan menjadi saudaramu adalah sebuah kebanggaan. Sebentar lagi kita akan berpisah, tapi aku akan selalu mendoakanmu.

Tuhan...

Lindungilah teman baikku ini. Berilah ia kemudahan dalam mencapai cita-cita. Buat dia selalu tersenyum. Buat juga dia selalu membuat orang lain tersenyum.

Engkau telah mempertemukan kami. Maka, pertemukan lagi kami kelak di surga-MU. Amin.

Malang, 25 Oktober 2018

$\sim K h^{\sim}$

Karya kreatif di atas hasil tulisan guru yang bergenre puisi naratif, yaitu puisi yang mengandung peristiwa tertentu yang membangun suatu cerita (Yuliati, 2005). Cerita yang dimaksud adalah cerita persahabatan. Di dalamnya, terkandung nilai-nilai atau amanat yang dapat membangun karakter anak. Nilai-nilai tersebut di antaranya adalah nilai moral, nilai sosial, dan nilai religius. Oleh karena itu, melalui pembacaan puisi karya guru ini siswa dapat belajar tentang persahabatan, budaya minta maaf, serta selalu bersyukur dan berdoa kepada Tuhan.

Kegiatan pengabdian diakhiri dengan diskusi terpumpun refleksi kegiatan. Hasil refleksi menunjukkan bahwa pihak sekolah mitra merasa terbantu oleh kegiatan ini. Melalui kegiatan ini, sekolah mitra mendapatkan pemahaman yang lebih baik tentang gerakan literasi sekolah dan literasi budaya. Pihak sekolah juga diuntungkan karena ada peningkatan kompetensi sumber daya manusia (SDM) dalam hal keterampilan menulis. Di sisi lain, guru juga merasa senang karena mereka tidak hanya mendapatkan materi tentang penulisan kreatif, tetapi juga mendapatkan inspirasi terkait metode pembelajaran menulis kreatif. 
Pada pelaksanaannya, kegiatan pengabdian kepada masyarakat ini memiliki beberapa kendala. Pertama, penyesuaian waktu antara tim pengabdi dan sekolah mitra. Kendala ini membuat pelaksanaan pengabdian tidak sesuai dengan jadwal yang disajikan di awal (proposal). Solusi yang diambil dari kendala ini adalah dengan memanfaatkan akhir pekan dan mengoptimalkan pertemuan nontatap muka. Kedua, rasa percaya diri guru. Guru-guru mengaku belum memiliki pengalaman menulis kreatif sehingga merasa kurang percaya diri dalam menulis. Kendala tersebut pada akhirnya dapat ditangani dengan baik melalui pelatihan dan pendampingan yang dilakukan.

\section{KESIMPULAN}

Kegiatan pengabdian kepada masyarakat bertujuan untuk memberikan pendampingan penulisan kreatif untuk mengoptimalkan pelaksanaan GLS kepada guru-guru di SDN Girimoyo 02, Kecamatan Karangploso, Kabupaten Malang. Penulisan kreatif ini berfokus pada tulisan kreatif yang berbasis budaya lokal. Secara umum, dapat dikatakan bahwa kegiatan pengabdian berjalan dengan baik. Meskipun terdapat kendala, kendala tersebut dapat diatasi hingga program selesai. Pihak-pihak terkait merasa senang dan program ini bermanfaat. Produk yang dihasilkan yaitu karya kreatif guru SDN Girimoyo 02 yang akan dijadikan sebagai bahan bacaan di perpustakaan SDN Girimoyo 02 Malang.

\section{UCAPAN TERIMA KASIH}

Ucapan terima kasih kami sampaikan kepada pihak-pihak terkait yang telah mendukung terlaksananya program pengabdian kepada masyarakat ini, terutama SDN Girimoyo 02 dan Direktorat Penelitian dan Pengabdian Masyarakat (DPPM) Universitas Muhammadiyah Malang.

\section{REFERENSI}

Aprinta, G. (2013). Fungsi media online sebagai media literasi budaya bagi generasi muda. Jurnal The Messenger, 5(1), 16-30. http://dx.doi.org/10.26623/themessenger.v5i1.218

Budiyono, H. (2012). Pembelajaran keterampilan menulis berbasis proses menulis dan teori pemerolehan bahasa. Pena : Jurnal Pendidikan Bahasa dan Sastra. 2(3). 86-98. https://doi.org/10.22437/pena.v10i1.10233.

Budiyono, H., \& Aryanti, P. T. (2016). Pengaruh penerapan model peta konsep dan penalaran terhadap kemampuan menulis esai mahasiswa. Bahasa Dan Seni: Jurnal Bahasa, Sastra, Seni Dan Pengajarannya, 44(1), 086-098. Retrieved from http://journal2.um.ac.id/index.php/jbs/article/view/207/171

Detik.com. (n.d.). Viral siswa pukul cleaning service, psikolog singgung kesalahan pola asuh. Detik.Com. https://health.detik.com/berita-detikhealth/d-4423520/viral-siswa-pukul-cleaning-service-psikolog-singgungkesalahan-pola-asuh?_ga=2.166841467.416920506.1598351090-964980267.159835109

Kemendikbud. (2016). Panduan gerakan literasi sekolah di sekolah dasar. Tim GLN Kementerian Pendidikan dan Kebudayaan Republik Indonesia. .

Kemendikbud. (2017). Pedoman penilaian dan evaluasi gerakan literasi nasional. 1-66. https://gln.kemdikbud.go.id/glnsite/wp-content/uploads/2017/08/pedoman-penilaian-evaluasi-gln.pdf

Liputan 6 Hot. (2020). 7 Faktor penyebab kenakalan remaja yang harus diperhatikan orang tua. https://hot.liputan6.com/read/4058611/7-faktor-penyebab-kenakalan-remaja-yang-harus-diperhatikan-orang-tua

Marliana, R., Indihadi, D., Marliana, R., \& Indihadi, D. (2020). Teknik brainstorming pada model pembelajaran menulis teks narasi. PEDADIDAKTIKA: Jurnal IImiah Pendidikan Guru Sekolah Dasar. 7 (2), 109-115. https://ejournal.upi.edu/index.php/pedadidaktika/article/view/25459.

Musaffak, \& Pangesti, F. (2018). Penerapan strategi mind mapping sebagai upaya peningkatan kemampuan mahasiswa dalam menulis artikel ilmiah. Belajar Bahasa, 3(2), 197-207. https://doi.org/10.32528/bb.v3i2.1589 .

Oktavianti., I., Zuliana., E., \& Ratnasari., Y. (2017). Menggagas kajian kearifan budaya lokal di sekolah dasar melalui gerakan literasi sekolah. Prosiding Seminar Nasional, 35-42. http://pgsd.umk.ac.id/files/prosiding/2017/5\%20lka\%20UMK.pdf.

Primadyaningsih, K., Kamsiyati, S., \& Markamah, E. S. (2016). Penggunaan Metode Pembelajaran Brainstorming untuk Meningkatkan Ktereampilan Menulis Pantun.

Rahmawati, N. (2017). Kenakalan remaja dan kedisiplinan: perspektif psikologi dan islam. Sawwa: Jurnal Studi Gender, 11(2), 267-288. http://dx.doi.org/10.21580/sa.v11i2.1458

Rosala, D. (2017). Pembelajaran seni budaya berbasis kearifan lokal dalam upaya membangun pendidikan karakter siswa di sekolah dasar. Ritme, 2(1), 16-25. https://ejournal.upi.edu/index.php/ritme/article/view/5078.

SindoNews.com. (n.d.). Tindak Kriminal Anak Sangat Memprihatinkan. SindoNews.Com. https://nasional.sindonews.com/berita/1386542/13/tindak-kriminalitas-anak-sangat-memprihatinkan

Supriyanto, E. (2017). Kedudukan Naskah Akademik Dalam Penafsiran Ketentuan-Ketentuan Dalam Undang-Undang. Yuridika, 31(3), 384-400. http://dx.doi.org/10.20473/ydk.v31i3.4822

Susilo, J., \& Wahyuni, V. E. (2017). Peran guru pembelajar sebagai pegiat gerakan literasi sekolah: tantangan dan solusi. 
http://fkip-unswagati.ac.id/ejournal/index.php/repository/article/view/268/252

Syaputra, A. F., \& Mantasiah. (2017). Keefektifan teknik brainstorming dalam keterampilan menulis karangan bahasa jerman siswa kelas xi ipa sma negeri 1 sungguminasa. Eralingua: Jurnal Pendidikan Bahasa Asing Dan Sastra, 1(2), 131-137. https://doi.org/10.26858/eralingua.v1i2.4409.

Triyono, T. (2019). Pentingnya literasi budaya di desa seni jurang blimbing. Anuva, 3(1), 77-85. https://doi.org/ 10.14710/anuva.3.1.77-85

Widyastuti, O. S., Mayor, J., \& Klaten, K. (2010). Menggunakan metode peta pikiran ( mind mapping) dalam menulis. September, 1-9.

Yuliati, A. (2018). Jenis puisi penyair muda bangkalan dalam kumpulan puisi bersama keluarga besar penyair bangkalan. NASPA Journal, 6(8), https://doi.org/10.31597/jsa.v6i2.207 